\title{
EFFECT OF EXTRACURRICULAR ACTIVITIES, INTRACURRICULAR ACTIVITIES AND CULTURE OF PESANTREN ON ENHANCEMENT OF STUDENTS LEARNING ACHIEVEMENT IN PP. BAITUL ARQOM JEMBER
}

\author{
Noga Riza Faisol ${ }^{1}$ \\ Gatot Sugeng Purwono ${ }^{2}$ \\ Agustin HP3 \\ Higher Education of Economic Mandala \\ e-mail: lintangauliazahira@gmail.com
}

\begin{abstract}
Pesantren (Islamic Boarding School) is one of the oldest educational systems in the archipelago (Indonesia). Classical method of a Kiai (religious leader of Moslem) as a figure and the mosque as a center of education proved to contribute knowledge and education character of the nation's children. Before modern education gives its influence, the classic, written or unwritten rules become a culture of positive direction for the santri (students of Islamic Boarding School) in it. Countless warriors and heroes in their era gave a share in the journey of this nation. Pesantren Modern is one of the evolutions of pesantren in responding to the development of the time. The principle of "Al mukhafadatualaalqodimiassholeh, walakhdualjadidi al aslah" or means keeping the good old tradition and take something new and better is a foothold in the management of the boarding school. The development is adjusted with the syllabus of the education curriculum in accordance of the level of elaborating the compulsory activities or called as Intracurricular activities as well as selected activities or Extracurricular. Another important role is the culture in surrounding pesantren as a container or synergy activities in everyday life. This article is more practical try to review the relationship of variables between the influence of extracurricular activities, intracurricular activities and pesantren culture on improving student achievement in PP. Baitul Arqom Jember. This study was used a quantitative approach by collecting primary and secondary data with various methods of data analysis and validity test to determine the level of validity and reliability.
\end{abstract}

\section{Keywords: Extracurricular, Intracurricular, Pesantren Culture, Achievement, Student}

\section{INTRODUCTION}

Pesantren world is one of the oldest educational institutions in Indonesia that until now still perform its existence. As one of the educational institutions that implement the full day system within 24 hours there will be many things accomplished in the system of forming one's character. Culture that emphasizes the ethics, knowledge and skills that become one is an effective container in the formation of the character. So the process is expected to be able to provide optimal results. Until later managed to make a referral system (Role Model) of human resources that ready to use and influential in society and in all aspects of life.

The journey of pesantren has evolved in accordance with the growth of knowledge itself. There are schools that adhere to the tradition with non-formal education as a teaching method (Shalafi), while another one aligned with the development of modern science that formulate formal education as an educational variant manages (Khalafi) (Qomar,2007:58). Neve rtheless, all of them still have the 
characteristic, which is making Kiai figure as the central education and activator in a boarding school. The central figure of that person fused with a set of ethics (morality itself), which became effective education to become so. This has made pesantren culture for hundreds of years spawned the figure of national role model who qualified in the scope of social, economic and academics.

Previous research reveals the relevance of both simultaneous and partial to the method of learning in various similar institutions. Intracurricular manifold activities: Full Day School (Netya Anggun Pratiwi, 2013) as well as various activities of the organization shall be in school (Ahmad Rusdi, 2010) contributes character and willingness to learn more, especially if the activity focuses on one lesson then the relevance of activities will become more significant (Eni Chandra Nur Hayati, 2013). Learning patterns will be unique because we do not know exactly where a motivation comes from. But with the reinforcement that comes from the environment by providing experience and appreciation of education will further affirm how should the pattern of education that occurred (Ana Purnama Dewi, 2012), especially an educational institution in the form of boarding school (Ani Khoirun Nisa, 2011).

Pondok Pesantren Baitul Arqom is one of the schools in Jember which applied Modern boarding school pattern (Khalafi). That system applied to the style of boarding school system that combines Gontor Darussalam curriculum (Ministry of Religious Affairs Republic of Indonesia) with curriculum system for alumnus of Gontor which has been applied among they themselves. The form of organizational implementation is steady in everyday activities, as well as the application of two foreign languages in the learning in the classroom and daily language in addition to the figure of a Kiai as a central figure. Besides to these activities, a variety of extra and intracurricular activities are strictly applied and implemented directly in everyday life. It is a kind of mandatory rhythm to be practiced by all santri. The existence of structurally tiered organization makes control of the activity applicable without accepting the reason for ignoring it. Sanctions will be given for those who violate the established rules. Pesantren culture brings its own characteristics in the implementation of extracurricular and intracurricular activities.

According to the Great Indonesian Dictionary, the curriculum means the subject matter taught by educational institutions (KBBI: 2014). Furthermore, the curriculum is seen as a system of learning programs to achieve institutional goals in educational institutions, so that the curriculum plays an important role in realizing a quality and dynamic school (Rusman, 2008: 01). As consequence, in every educational institution where the system plays as driving tool, the curriculum will be a very vital part. Any kinds of outline, direction, purpose and output will be driven by the utility and characteristics that through the time being was built by all the experience that has been planned to prepare students to achieve educational goals (Rusman, 2008: 21).

As for things that are very concerned in the preparation of a curriculum, among others:

1. Productivity

The results to be obtained in curriculum activities are aspects that should be considered in curriculum management. Consideration of how the learners can achieve learning outcomes in accordance with the objectives.

2. Democratization

It should be based on a democracy that puts the manager, executor and subject of educator in a position that should be in carrying out the task of full responsibility. 
3. Cooperative

There needs to be a positive cooperation from various parties involved.

4. Effectiveness and efficiency

It needs to consider the effectiveness and efficiency to achieve the curriculum objectives so that these activities provide useful results with cost, and a relatively short time.

5. Directing vision, mission and goals

The ongoing process should be able to strengthen and direct the vision, mission, and objectives of the curriculum (Rusman, 2008: 04).

Linguistically, extra is a form bound outside and intra means bound within. Extra is known as free while intra is an activity that is bound within the learning device included in the learning effort both within and outside the learning device.

In other words, the concept of extra and intracurricular activities is part of the implementation of self-development activities contained in the Regulation of the Minister of National Education No. 22 of 2006 as follows. "Self-development is not a subject to be cared for by teachers. Self-development aims to give opportunities to learners to develop and express themselves in accordance with the needs, talents, and interests of each learner in accordance with the conditions of the school. Self-development activities facilitated and guided by counselors, teachers, or educational personnel that can be done in the form of extracurricular activities. Self-development activities are conducted through counseling services related to personal issues and social life, learning, and career development of learners (Rusman, 2008: 415).

The development of education is not only derived from academic theoretical activities but also the development of civilization is more directed to the formation of personality where learners get closer to the mental possession and fighting for the future. Practically, it can be done outside regular effective hours, with more flexible supervisors coming from teachers' boards or competent authorities in their fields. As for the essential characteristics of each type of curricular activities can be described in the table as follows:

Table 2.1

\begin{tabular}{|c|l|l|}
\hline ASPECT & \multicolumn{1}{|c|}{ INTRACURRICULAR } & \multicolumn{1}{|c|}{ EXTRACURRICULAR } \\
\hline Goals and Functions & $\begin{array}{l}\text { Provide affective, } \\
\text { (cognitive, in the } \\
\text { psychomotor) } \begin{array}{r}\text { in } \\
\text { accordance with prescribed } \\
\text { curricular goals. }\end{array}\end{array}$ & $\begin{array}{l}\text { Provide experiences that } \\
\text { match the hobbies, talents, } \\
\text { interests and abilities of } \\
\text { learners. }\end{array}$ \\
\hline Content & $\begin{array}{l}\text { Specified in the syllabus of } \\
\text { each subject. }\end{array}$ & $\begin{array}{l}\text { Adapted to of } \\
\text { characteristics of learners } \\
\text { and school conditions. }\end{array}$ \\
\hline Activities & In the Lesson. & Outside of lessons \\
\hline Program & Terpogram & Terpogram \\
\hline Evaluation & $\begin{array}{l}\text { Daily repeat, general repeat } \\
\text { (end of Program) }\end{array}$ & $\begin{array}{l}\text { Evaluation } \\
\text { Development, Evaluation } \\
\text { of Action }\end{array}$ \\
\hline Subjects & $\begin{array}{l}\text { Regular class attendees } \\
\text { (required by all students) }\end{array}$ & $\begin{array}{l}\text { Participants of the Special } \\
\text { Class (by Choice). }\end{array}$ \\
\hline
\end{tabular}

Source (Rusman, 20: 2009). 
According to the Great Indonesian Dictionary, "Culture" is defined as thought, reason, or custom (KBBI, 2014; 214). In other words everything produced by humans will be called as an outcome of culture. According to the pioneer of Modern Anthropology, Edward B. Taylor, in his primitive culture defines culture as follows: "Culture or civilization is a complex whole of knowledge, belief, art, morals, law, customs, and abilities and other habits acquired by man as a member of society" (Tilaar, 1999: 39).

As a human being, many dynamics are always generated. At the certain level relating to humans a culture is formed either in the section of social and political, technological and art. Those all include at the infinite dimension of the culture. Culture covers wherever humans are, free from the dimension of cultural time which also changes in every aspect. Both demographic and sociological culture will depend on where the man showed his existence. According to Koentjaraningrat, culture has at least three forms, namely:

1. The form of culture as a complex of ideas, thoughts, values, regulatory norms and so on.

2. Beings of culture as a complex of activity, patterned behavior of humans in society.

3. Beings of culture as objects of human works (Koentjaningrat, 1975: 19).

Thus the world of education will also experience a different culture. The system or process that takes place will form a separate culture. System is culture, learning process is culture, attitude toward teacher and student also a part of culture. In addition, the culture in the world of education can be defined in the following framework:

1. Culture is a complex whole. This means that culture is a unity and not a sum of parts. They all have unique designs or patterns. Each culture has a specific mosaic.

2. Culture is a human creation achievement that a-material means in the form of psychological achievements such as science, belief, art, and so forth.

3. Culture can also be physical as a result of art, the formation of family groups.

4. Culture can also take the form of directed behaviors such as law, sustainable customs.

5. Culture is an objective reality, which can be seen.

6. Culture is obtained from the environment.

7. Culture does not materialize in a solitary or alienated human life but who lives in a particular society (Tilaar 1999: 40).

Thus in the world of cultural education can be concluded that culture is all things that inspire learners in the learning process either directly or indirectly, both in thoughts, words and deeds.

a. Culture and Education

Along with culture, education also provides immediate implications for the development of human life. Because humans are always in a state of processing, then education is also a pillar that forms a culture itself. It cannot be separated. Men forever develop knowledge and who they are. In certain point need a set of logic and ethics that can form a civilization becomes better. And this is where the role of education applies truly. It is given concept of behaving, thinking, even assessing everything in accordance with applicable law. Education becomes a tool for progression of a nation and always gets the most important place in progress.

Long before that was Indonesian Education Father Ki Hadjar Dewantara that formulated a vital role of education in culture. They rae as follows:

1) Culture cannot be separated from education; even culture is the foundation or basis of education.

2) Culture that is the reason for the education must be national. Thus the culture in question is a real culture that is a living culture within the society of Indonesian nationality. 
3) Education has a direction that is to realize the needs of life. What is meant by life is not only an aspect but the whole of human life.

4) The direction of the goal of education is to elevate the state and the people. Visionary education (Tilaar, 1999: 70).

From the above formula it can be concluded that education and culture is not separate. And will always be the spirit for the development of civilization of a nation.

In the Great Indonesian Dictionary, the word "Santri" is defined as a person who deepens Islam, people who worship sincerely or as a soleh (KBBI: 2014). Those who study religious knowledge more intensely also terminology entered in santri category. More standardized in Sociology by Clifort Gertz santri became a wider circle of its own aligned with the Islamic Kejawen called the abangan and the pure one called the nobility.

The institution where the santri live is generally called "Pesantren". Or the house is called "Pondok Pesantren". Where the naming of the residence of the santri community is always placed at the beginning as an identity before the name of a pesantren is pinned. This is inseparable from the history of mention of the term "Pondok" itself. Pondok pesantren is a meaning at the beginning as a house or a simple residence made of bamboo (cottage). Besides, the word "Pondok" may also be derived from the Arabic "funduq" which means the hotel or hostel (Hasbullah, 1999: 138). While the pesantren originated from the word santri that has been mentioned at the beginning.

The santri education system is different from the normative education system in general. Survival of a pesantren is highly dependent on the appeal of the central figure (Kiai or Guru) who leads, continues or inherits it. If the heirs fully master the religious knowledge, prestige, teaching skills and other necessary wealth, then the age of the pesantren will last long. Instead the pesantren will retreat and may disappear, if the heir or the offspring of Kiai who inherit it do not meet the requirements (Hasbullah, 1999: 139). Starts from here, the dynamics of pesantren is experiencing many developments. Adaptation with the existence of modern knowledge and skills needed to make the boarding schools are divided into two types:

1. Traditional Boarding School (Pesantren Salafi).

It is the oldest form of Islamic educational institution in Indonesia. Where the central role of Kiai as figure is sometimes trapped in the cult of the individual. Where the daily activities of santri are centered on the Kiai guidance both in the teaching system and the regeneration of institutions. This is what often does not have significant correlation with the power of management. (Qomar, 2007: 59).

2. Modern Pesantren (Pesantren Khalafi) It is a form of Islamic educational institutions that are more adaptive. Adaptation is done in the development and change of education which is the result of the guidance of the development of modern science and technology (Qomar, 2007: 58).

Thus, students are a group of students with a variety of uniqueness with a separate learning system that includes:

1. Intellectual Education

Includes basic education and teaching of Shari'a science applied both adaptively and derived from the classical books.

2. Community Social Education

It is an education that governs relationships with people. In this case, called $m u$, amalah or $m u$, asyarah (hang). In this field can be seen from the teaching field right to the heirs (fara, id), zakat, living or fulfillment of daily living

3. Population Education. 
The purpose of population education is to foster learners to have understanding, awareness and responsibility towards the realization of a happy family of the world and the hereafter on a micro scale.

4. Sports and Health Education Is an education with the provision of sports as a form of physical and spiritual health development efforts contained in various forms of sports.

5. Skills Education

It is a skill given to equip students in life after leaving pesantren. For instance, by learning Arabic and English language as well as computer skills (Zubaedi, 2007: 212).

In the Great Indonesian Dictionary, the increase in the meaning of the word meaningful level of layered or plaited arrangement such as house lenggek (KBBI: 2014). While the increase refers to the meaning of the process of improvement as well as an increase in business.

While the meaning of achievement is the result that has been achieved (KBBI: 2014). In this case more achievement leads to academic results contained in the collection of values from various lessons in take.In the assessment of subjects and attitudes of everyday a santri.

Further assessments are a set of values that are based on various Indicators. Those can be done using tests and non tests in written or oral form, performance observation, attitude measurement, assessment of work in the form of tasks, projects, and or products, portfolio use, and self-assessment.

The things that need to be considered in the assessment are the following:

a) Assessment is directed to measure the achievement of competence.

b) Assessment using the criterion reference, namely based on what can be done learners after following the learning process. c) The planned system is an ongoing assessment system. In the sense that all Indicators are billed, then the results are analyzed to determine the basic competencies that have been and which have not, as well as to know the difficulties of learners.

d) Assessment results are analyzed to determine follow-up. Follow-up in the form of improvement of the next learning process, remedial program for learners who achievement of their competence under the criteria mastery, and enrichment program for learners who have met the criteria mastery.

e) The assessment system should be tailored to the learning experience pursued in the learning process. For example, if using a field observation approach, evaluation should be given either to process (process skills) such as interview techniques, or products or outcomes that make field observations in the form of information required (Rusman, 2008: 413).

Learning is the beginning of a teaching and gives meaningful instructions to someone to be known. While learning is a process or way of gaining knowledge (KBBI: 2014). In other words learning is a process of deed in gaining knowledge. In this case there is certainly a system and objectives to be studied. Further learning is a process done by individuals to gain a new behavioral change as a whole, as a result of their own experiences in interaction with their environment (Rusman, 2008: 372).

In the learning process many things must be considered as both teachers and learners who receive the learning process. The various laws and principles include:

a) Conformity (relevance), That is, every type of teaching skills applied must be tailored to 
the components or other learning variables (internal and external).

b) Creativity and innovative,

That is every type of basic teaching skills that are applied in a creative and innovative so as to encourage activity and creativity of student learning optimally.

c) Accuracy,

That each type of basic teaching skill applied should be selected, both in quality and quantity so that each type and form of basic teaching skills applied achieves the expected learning objectives.

d) Benefit,

Each type of basic teaching skills applied can contribute or have a high value of benefits for the development of student potential both academically and non academically.

e) Pleasant,

That cooptation and application of any kind of teaching basic skills endeavored to create an atmosphere of learning the exciting and fun (Joyfull Learning) (Rusman, 2008: 375).

If it is freely translated, the improvement of learning is an attempt to improve one's learning process. In this case, it refers to a learning system applied within an institution in improving the quality and quantity of individuals.

\section{Effect of Extracurricular Activities on Students Learning Achievement}

Extracurricular activities are basically the development of curriculum that is taught. The dynamics of students' development is very diverse then it takes an activity unit that can direct the talents and interests of learners more intensely. Further extracurricular activities are out-of-school educational activities and counseling services to assist student development in accordance with their needs, potentials, talents, interests that are specifically held by educators or education personnel who are capable and authorized in school or madarasah (Rusman , 2008: 20).

In the various researches conducted, the fertilization of talents and interests of learners can be a catalyst for the development of learning achievements to become more effective (Eni Chandra NurHayati: 2013).

\section{The Effect of Intracurricular Activities on Students Learning Achievement}

Basically, the differences between intra and extracurricular activities are only found at the implementation level. The name of intra is more inclusive in formal lessons and is mandatory for regular learners and also more general. The success rate of extracurricular activities if combined in a comprehensive manner with intracurricular activities will provide more effective results for curricular development (Rusman, 2008: 20).

\section{The Influence of Pesantren Culture on Student Achievement of Santri}

One of the benefits of pesantren is the creation of a conducive climate for the learning system. Within pesantren there is a set of rules that are obeyed together that can create and direct students into a better person. It is by $\mathrm{Ki}$ Hadjar Dewantara called concept and Peguron system based on family life to unite the teaching of knowledge with teaching manners (Tilaar, 1999: 44). The unification of several aspects of education within the pesantren is what makes the effectiveness of learning increased (MitaAnggraeni, 2011).

\section{RESEARCH METHODS}

This type of research was Quantitative Research methods that use statistical data. This study used descriptive statistic method i.e. statistic that serves to describe or give an idea of the object under 
study through sample data or population as it is, without doing analysis and make conclusions that apply to the public (Sugiyono, 2013: 29).

In this study, there are two identification variables, namely:

a. Independent Variables

They are variables that affect or cause changes or the emergence of the dependent variable. In this case, Extracurricular and Intracurricular Activities are including into free variables.

b. Dependent Variables
Dependent variables are the thing that becomes the result that caused by the independent variable. In this study, Student Achievement is a bound variable.

\section{Intracurricular Activities}

Intracurricular activity is an obligatory activity for every student in PP. Baitul Arqom Jember. This organization is comprehensive and becomes the driving force for the daily activities of santri.

Table 3.1

\begin{tabular}{|l|l|l|}
\hline \multicolumn{1}{|c|}{ Variable } & \multicolumn{1}{|c|}{ Indicator } & \multicolumn{2}{|c|}{ Item Statement } \\
\hline \multirow{4}{*}{$\begin{array}{l}\text { Intracurricular } \\
\text { Activities }\end{array}$} & 1. Cognitive activity & $\begin{array}{l}\text { 1. The addition of santri's } \\
\text { intelligence }\end{array}$ \\
\cline { 2 - 4 } & $2 . \quad \begin{array}{l}\text { Affective } \\
\text { activities }\end{array}$ & $\begin{array}{l}\text { 2. The development of polite } \\
\text { attitude }\end{array}$ \\
\cline { 2 - 4 } & 3. $\begin{array}{l}\text { Psychomotor } \\
\text { activity }\end{array}$ & $\begin{array}{l}\text { 3. The existence of academic } \\
\text { behavior }\end{array}$ \\
\hline
\end{tabular}

\section{Extracurricular activities}

It is an alternative activity that can be an optional choice of supporting activities for a santri. This activity is held in accordance with the talents and interests according to the aspirations of tsantri.

Table 3.2.

\begin{tabular}{|l|l|l|}
\hline \multicolumn{1}{|c|}{ Variable } & \multicolumn{1}{|c|}{ Indicator } & \multicolumn{1}{|c|}{ Item Statement } \\
\hline $\begin{array}{l}\text { Extracurricular } \\
\text { activities }\end{array}$ & $\begin{array}{l}\text { 1. There is interest in following the } \\
\text { activity. } \\
\text { In accordance with the } \\
\text { talents and interests of } \\
\text { students }\end{array}$ & $\begin{array}{l}\text { The existence of skill } \\
\text { development in following the } \\
\text { activity. } \\
\text { 3. The existence of the organization } \\
\text { in accordance with the similarity } \\
\text { of interest. }\end{array}$ \\
\hline
\end{tabular}

\section{Culture of Pesantren}

According to the exposure of experts that Koentjaraningrat states that culture has at least several forms, which include in the dynamics of human life. It is an accumulation of every facet of human needs. It can be seen as follows: 
Table 3.3

\begin{tabular}{|c|c|c|}
\hline Variable & Indicator & Item Statement \\
\hline (1) & (2) & (3) \\
\hline \multirow{3}{*}{$\begin{array}{l}\text { Culture of } \\
\text { Pesantren }\end{array}$} & 1. $\begin{array}{l}\text { Tangible } \\
\text { written rules }\end{array}$ & $\begin{array}{l}\text { 1. The regulation is mandatory. } \\
\text { 2. The existence of sanctions if it violates } \\
\text { the rules } \\
\text { 3. The regulation concerns all the activities } \\
\text { of santri in pesantren. }\end{array}$ \\
\hline & $\begin{array}{l}\text { 2. Tangible daily } \\
\text { activities }\end{array}$ & $\begin{array}{l}\text { 1. Usually done by all santri. } \\
\text { 2. The absence of compulsion in doing } \\
\text { these activities. } \\
\text { 3. This activity is almost done by all santri } \\
\text { from several periods. }\end{array}$ \\
\hline & $\begin{array}{ll}\text { 3. } & \text { Tangible } \\
\text { objects used }\end{array}$ & $\begin{array}{l}\text { 1. Always used by all santri. } \\
\text { 2. Used in everyday santri. } \\
\text { 3. Used in helping students learn. }\end{array}$ \\
\hline
\end{tabular}

\section{Students Learning Achievements}

Achievements can be analyzed if they consist of a variety of supportive values. One such indicator is the result of a semiannual report consisting of a Report Card of each student. Which consists of various natijah or the value of the various subjects taught, the assessment also directly or indirectly way. This is also evidenced by the student report card in the odd semester.

Method of data collection in this research use primary and secondary data. Primary data is used through direct interview process or by using a closed questionnaire distributed to respondents. While the secondary data using relevant documents that support the object of research.

While the definition of an interview is a form of verbal communication that aims to obtain information (Pabundu Tika, 2005). These data collection methods are including:

a. Questionnaire

This is a closed questionnaire consisting of two parts, the respondent's personal data for the first part, and the item of the constructor or variable statement used in the model for the second part. Data collection is done directly by requesting the respondent's willingness to fill out the questionnaire in the workplace.

b. Interview

Is a process to obtain information by way of direct meeting with respondents or related parties to support the data obtained through the questionnaire.

c. Literature review

Obtained by reading the literatures associated with the problems studied, in the form of theories proposed by experts associated with research which obtained from: books, journals, previous research and the internet.

This research method was using Multiple Regression data analysis method. It means if the researcher intends to predict how the situation (ups and downs) of the dependent variable (Criterium), if two or more independent variables as the predictor factor is manipulated (should decrease its value). So multiple regression analysis will be done when the number of independent variables provided at least two (Sugiyono, 275: 2013).

This validity test is used to determine the level of validity and level of reliability. 
a. Validity test

Any item in the instrument is valid or not, can be known by correlating between the score of the item with the total score. When the value of correlation is below 0.30 , it can be concluded that the clause is not a valid instrument, so it must be repaired or discarded.

\section{b. Test Reliability}

According to Ghozali (2005) in Dimyati (2009), it is stated the value of which is used to assess the level of reliability that can be accepted is 0.70 , when the study was explore then the value below 0.70 is acceptable if data are reasons empirically that seen in the exploration process.

\section{c. Normality test}

To determine whether the data taken from the population and a normal distribution is necessary to test for normality or not, there are several techniques that can be used to test the normality of the data, among others: the norm opportunities paper, chisquare test, Liliefors test and KolmogorovSmirnov techniques, and SPSS.

This study used SPSS techniques: SPSS 16.0. The set of SPSS program will produce 4 types of output, namely 1) Processing Summary, 2) Descriptive, 3) test of normality, and 4) QQ plots. For the purposes of research generally required only output a test of normality. Of the output data can be seen in the column Kolmogorov-Smirnov, how to pay attention to a significant, or insignificant normality test results is by looking at the numbers in the column of significance (Sig.) To establish normalcy, if the significance of which was obtained $>\alpha$ (0.05) then the samples come from populations with normal distribution, and if a significant acquired $<\alpha(0.05)$ then the samples come from populations which is not normally distributed (Juliansyah Noor, 2011: 177-178).

\section{d. Linearity test}

Linearity test is performed to determine whether the relationship between the dependent and independent variables is linear (straight line). Linearity test on this study will be done by using SPSS 16.0. In SPSS, there will be produced Interactive Graph which has pointed out the regression line. If the regression line shown on the lower left to the upper right, then the dependent and independent variables have a relationship liniear. The other way if the linear regression line looks flat from left to right, means the dependent and independent variables has no linear relationship (Muhammad Nisfiannorr, 2009: 103-108).

\section{e. Heteroscedasticity test}

Heteroscedasticity is a test to determine whether disruption variable in the regression equation have the same variant or not. Heteroscedasticity symptoms occur as a result of the inequality of the data, so the variation of the value of the data to determine whether there researched. It was detected heteroscedasticity case or not. Basis for decision making based on the opinions of Kuncoro (2007) as follows:

1. If certain patterns appeared, such as dots that form a particular pattern, then it has happened heteroscedasticity;

2. If there is no clear pattern, as well as the points spread above and below the number 0 on the $\mathrm{Y}$ axis, then there is no heteroscedasticity.

\section{f. Multiple Linear Regression Analysis}

Multiple linear regression analysis is used to determine the effect of the independent variable to dependent variable. Analysis articles used by the researchers in this study are multiple regression analysis. If researchers intend to predict how is the situation (rise and fall) 
of the dependent variable (criterion), when two or more independent variables as a factor predicting manipulated (lower value increased). Therefore multiple regression analysis will be carried out if the amount of at least two independent variables (Sugiyono, 2012).

The equation of the regression is as follows:

$\mathrm{Y}=\mathrm{a}+\mathrm{b} 1 \mathrm{x} 1+\mathrm{b} 2 \mathrm{X} 2+\mathrm{b} 3 \mathrm{X} 3+\mathrm{e}$

Information:

$\mathrm{Y}=$ Students Achievement

$\mathrm{a}=$ Constant

$\mathrm{b}=$ Coefficient of Linear Regression

$\mathrm{X} 1=$ Extracurricular Activity

$\mathrm{X} 2=$ Intracurricular Activities

X3 = Culture of Pesantren

$\mathrm{e}=$ Error

\section{RESULT ANALYSIS}

$\mathrm{T}$ test (partial test) The t-test is used to determine the effect of each independent variable on the dependent variations. Criteria value $t$ test with significance level of 5\%, as follows:

1. If $\mathrm{t}>\mathrm{t}$ table, then the hypothesis is accepted.

2. If $\mathrm{t}<\mathrm{t}$ table, then the hypothesis is rejected

$\mathrm{F}$ test (simultaneous test) $\mathrm{F}$ test is used to determine the effect of independent variables together (simultaneously) to bond variable. The significant one is meaningful relationships that occur can apply to the population. The use of the significance of the $\mathrm{F}$ test are various, which is $0.01(1 \%) ; 0.05(5 \%)$; and 0.10 $(10 \%)$. If the probability value $<0.05$, it can be said to be a significant influence jointly between independent variables on the dependent variable. However, if the significance value $>0.05$, it means there is no significant effect jointly between independent variables on the dependent variable.

Coefficient determination (R2) The coefficient of determination (R2) was used to measure the contribution of several independent variables to variations downs dependent. The variable is usually expressed in percentage.

\section{INTERPRETATION}

\section{The Effect of Extracurricular Activities on Student Learning Achievement}

Extracurricular activities are optional activities that not all santri follow those activities. Activities consists of sports activities such as basketball, volleyball, soccer, martial arts, and so forth. In art, there are activities such as theater, marching bands and spiritual activities. These activities are selected according to individual interests. Although the choice is almost certain all santri are incorporated in this range of extracurricular.

The results stated that extracurricular has an effect on the students learning achievement. Based on the research of various extracurricular in pesantren, it is known that the t-count value of the extra activity variable is 2,611 with the significance value of 0,015 . Values of significance ( $p$-value) of 0.015 is smaller than $\alpha(0.05)$ which indicates that the variable partial extra activities have a significant influence on learning achievement of students. It means that extracurricular has an influence on student achievement partially or separately by 2,611 from the number of $100 \%$ of the three variables studied. This becomes the second largest factor after the intracurricular activity in affecting the students learning achievement in PP Baitul Arqom Jember. Besides having a separate influence, extracurricular also affect student learning achievement simultaneously or all at once with two other variables.

\section{The Effect of Intracurricular on Students Learning Achievement}

Intracurricular is a mandatory activity that should be done by all santri. It 
is expected that as a basic provision for them. The fields of organizational activities like scouting, rhetoric, and teaching ability become the thing that must be mastered by the santri. Thus all intracurricular activities become the basis of every activity of santri to be accomplished.

Based on the result of research of intracurricular activity has positive effect to students learning achievement. Based on the 3 variables studied, intracurricular is the dominant factor affecting students learning achievement. Known value of $t$ count variable of intracurricular activity is equal to 2,867 with significance value equal to 0,008 . Values of significance $(p$ value) of 0.008 is smaller than $\alpha(0.05)$ indicates that the variable partial of intracurricular activities has a significant influence on learning achievement of students. It means that intracurricular activity has partially or separately influence to student achievement equal to 2,867 from $100 \%$ nominal accumulation of 3 variables studied. In addition to intracurricular activities separately or partially become the dominant factor in influencing student learning achievement also be a factor that all at once or together with two other factors in affect to learning achievement students in PP Baitul Arqom Jember.

\section{Influence of Culture to Learning of Santri.}

\section{Pesantren Achievement}

Pesantren culture is a container that is formed due to something done repeatedly. In this case extra or intracurricular activities become the cause of the formation of the culture. Something that is required in the form of activities will take root in the subconscious makes no compulsion in doing these activities. This makes pesantren has its own distinctive culture according to the activities cultivated in every day. The process of adaptation of santri with extra and intracurricular in daily activities makes pesantren culture as a separate culture followed by every santri who stay there.

Based on the research result, pesantren culture has an influence on student learning achievement. Of the 3 variables studied, pesantren culture is the smallest factor affecting student achievement of santri. It is known that $\mathrm{t}-$ count value of pesantren culture variable is 2,315 with significance value equal to 0,029 . Value of significance ( $p$-value) of 0.015 is smaller than $\alpha(0.05)$ indicates that the variable partial of boarding culture has a significant influence on learning achievement of students. This means that the culture that makes the effect of the accumulation of daily activities is also an influential factor in student achievement of 2.315. This value is the smallest value among the three research variables. Regardless of the nominal dominance in influencing the learning achievement of santri, without cultural involvement in the sense of everyday activities that have been formed in the deeds, objects or words of any activity will not have an emotionally strong influence to enter in the subconscious factors.

\section{CONCLUSIONS}

Based on the result and discussion about the influence of extracurricular activities, intracurricular activities and pesantren culture on the students learning achievement in PP. Baitul Arqom BalungJember, it can be concluded that Extracurricular activities, intracurricular activities and pesantren culture all at once have a significant effect on student achievement in PP. Baitul Arqom BalungJember. Extracurricular activities, intracurricular activities and pesantren culture partially have significant effect on student achievement in PP. Baitul Arqom Balung-Jember with the most significant influence is dominate by intracurricular activities, then the extracurricular activities 
and the last pesantren culture. Effective summons of extracurricular activities, intracurricular activities and pesantren culture on students learning achievement in PP. Baitul Arqom Balung-Jember is equal to $71,4 \%$ with variable of intracurricular activity as the most dominant variable $(29,6 \%)$.

\section{IMPLICATIONS}

Basically, pesantren activity is well structured and arranged. If being articulated, there is a separate schedule which covers all santri activities starting from early morning until late night. This repetitive and periodical course has its own contribution for santri. With the study that has been performed by researchers in several variables that have been determined, then of these three variables, intracurricular activities have a dominant effect on student achievement of santri. This can be interpreted in the development of pesantren, namely: Intracurricular activity is the dominant factor that forming characteristics of santri. It is expected the existence of activity development and also periodical evaluation for the quality of activity. Extracurricular activities as the second dominant factor is the existence of the potential diversity of santri which is expected to develop better. The culture of pesantren which is the container of these two factors is the result of the happening and make the culture felt and agreed together to continue to be done.

In contrast to previous research, as empirical basis of authors in preparing the hypothesis of cultural trends is a dominant factor that affects the learning achievement of santri. Characteristic of traditional pesantren and modern pesantren will affect the mindset and learning achievement of santri.

\section{REFERENCES}

Ferdinand, Augusty ," "Structural Equation Modeling: In PenelitianManajemen " 2006. BP Undip: Semarang

Hasbullah ,. " History of Islamic Education DI Indonesia " .1999. Third mold,. PT RajaGrafindoPersada: Jakarta

Indonesian Dictionary, 2014. Fourteen Edition

Koentjaraningrat, " Culture, Mentalitet and Development ", in 1976 ,. Gramedia: Jakarta

.Nur, Juliansyah. " The research methodology: Theses, Dissertations and Scientific Work " .2011.Kencana Prenada Media Group: Jakarta

Omar, Mujamil ,. Prof ,. DR. " Islamic Education Management " Erland 2007..Penerbit ..

Rusman, DR. M.Pd. " Management Curriculum " .2008. PT. King Grafindo: Jakarta

Sabarguna, Dr.dr.H.Boys. MARS " Data Analysis On Qualitative Research " 2008. UI Press:

Sugiyono, .Prof. DR "Research Procedure A Practical Approach". 2006. Publisher PT Rineka Reserved. Molds to-13

Sugiyono, .Prof. DR. " Statistics For Research ". 2013. Publisher

Alfabeta. Molds to-23: Bandung.

Tilaar, Prof., DR, M.Sc, .Ed. " Education, Kebudayan and Indonesian Civil Society ". 1999. Publisher PT. Youth Rosdakarya: Bandung

Zubaedi, 2007, Empowerment PesantrenBased Society " First Cetakan. Pustaka Pelajar. 